\title{
PENGARUH RETURN ON INVESTMENT (ROI), ECONOMIC VALUE ADDED (EVA) DAN CURRENT RASIO (CR) TERHADAPRETURNSAHAM
}

\author{
Ikmal Hamdani \\ Fakultas Ekonomi dan Sosial UIN Sultan Syarif Kasim Riau - Pekanbaru \\ E-mail: ikmalhamdani74@gmail.com \\ Nurlasera \\ Fakultas Ekonomi dan Sosial UIN Sultan Syarif Kasim Riau - Pekanbaru \\ E-mail: nurlasera@uin-suska.ac.id
}

\begin{abstract}
Abstrak
Penelitian ini bertujuan untuk menguji pengaruh variabel Return On Investment, Economic Value Added dan Current Ratio terhadap return saham. Data yang digunakan adalah data sekunderyaitu. Populasi dalam penelitian ini adalah perusahaan perkebunan yang terdaftar di Bursa Efek Indonesia tahun 2010-2014. metode pengambilan sampel menggunakan teknik purposive samplingdenganmengambil 8 perusahaan yang menjadi sampel. Metode analisis yang digunakan pada penelitian ini adalah analisis regresi data panel dengan bantuan program Eviews 6.0. Hasil pengujian secara parsial menunjukkan bahwa Return On InvestmentReturn On Investment dan Economic Value Added berpengaruh positif signifikan terhadap return saham. Sedangkan Current Ratio tidak berpengaruh secara signifikan terhadap return saham. Hasil uji simultan menunjukkan bahwa secara bersama-sama Return On InvestmentReturn On Investment, Economic Value Added dan Current Ratio berpengaruh secara signifikan terhadap return saham. Nilai Adjusted $R$ square adalah 56,15\%, hal ini berarti 56,15\% variabel dependen dapat dijelaskan oleh variabel independen, sedangkan sisanya 43,85\% dijelasakan oleh sebab-sebab lain diluar model.
\end{abstract}

Kata kunci: Return On Investment (ROI), Economic Value Added (EVA), Current Rasio (CR), Return Saham.

\section{PENDAHULUAN}

Di era ekonomi modern seperti sekarang ini, dunia usaha menjadi semakin kompetitif sehingga menuntut perusahaan untuk mampu beradaptasi agar terhindar dari kebangkrutan dan unggul dalam persaingan. Untuk mengantisipasi persaingan tersebut, perusahaan harus mempertahankan dan meningkatkan kinerja sebagai upaya menjaga kelangsungan usahanya.
Upaya yang dapat di lakukan antara lain menerapkan kebijakan strategis yang menghasilkan efisiensi dan efektifitas bagi perusahaan. Usaha tersebut memerlukan modal yang banyak, yang meliputi usaha memperoleh dan mengalokasikan modal tersebut secara optimal. Salah satu tempat untuk memperoleh modal tersebut adalah melalui pasar modal. 
Pasar modal adalah pasar keuangan untuk dana jangka panjang dan merupakan pasar yang konkret. Pasar modal mempunyai peranan sangat penting, hal ini di karenakan pasar modal menjalankan fungsi ekonomis sekaligus fungsi keuangan ekonomi, dari fungsi ekonomi pasar modal berfungsi sebagai menyediakan fasilitas atau wahana untuk mempertemukan dua kepentingan, yaitu pihak yang memiliki kelebihan dana (investor) dan pihak yang membutuhkan dana atau disebut issuer (pihak yang menerbitkan efek atau emiten). Dengan adanya pasar modal, maka pihak yang memiliki kelebihan dana dapat menginvestasikan dana tersebut dengan harapan memperoleh imbalan hasil (return), sedangkan pihak issuer dapat memampaatkan dana tersebut untuk kepentingan investasi tanpa harus menunggu tersedianya dana dari operasi perusahaan. Pasar modal di Indonesia memang salah satu dari emerging market yang masih dilirik investor.

Investor pada umumnya membeli suatu saham dengan harapan agar menerima devidend dan capital gain serta tingkat keyakinan yang relatif bahwa investasi mereka akan terjamin, walaupun resiko akan gagal ada dalam setiap investasi. Untuk memastikan apakah investasinya akan memberikan tingkat pengembalian yang di harapkan, maka calon investor terlebih dahulu mencari informasi keuangan melalui laporan keuangannya.

Salah satu informasi penting dari laporan keuangan yang sering di gunakan investor sebagai determinan utama pengambilan keputusan investasi adalah kinerja perusahaan. Kinerja perusahaan ini mencerminkan kekuatan perusahan yang angka-angkanya di ambil dari laporan keuangan. Salah satu informasi akuntansi yang penting dalam proses penilaian kinerja perusahaan adalah berupa rasio-rasio keuangan perusahaan untuk periode tertentu. Dengan rasio-rasio keuangan tersebut akan tampak jelas berbagai indikator keuangan yang dapat mengungkapkan kondisi keuangan suatu perusahaan maupun kinerja yang telah dicapai perusahaan untuk suatu periode tertentu.

banyak faktor yang mempengaruhi pergerakan return saham. Para investor perlu melakukan analisis yang mendalam mengenai perubahan tersebut. Salah satu caranya adalah dengan melakukan analisis fundamental yang berbasis rasio keuangan. Rasio yang sering digunakan adalah return on investment (ROI).

Return on investment (ROI) merupakan perbandingan antara laba bersih setelah pajak dengan total investasi rata-rata. ROI adalah rasio yang di gunakan untuk mengukur keuntungan bersih yang diperoleh dari penggunaan aset.Namun, penggunaan alat ukur terhadap laba akuntansi seperti ROI (return on investment) memiliki kelemahan yaitu tidak memperhatikan resiko yang di hadapi perusahaan dengan mengabaikan adanya biaya modal dan hanya memperhatikan hasilnya (laba perusahaan) sehingga sulit untuk mengetahui apakah perusahaan tersebut telah berhasil menciptakan nilai perusahaan atau tidak. 
Untuk mengatasi kelemahan tersebut, Stewart dan Stern seorang analisis keuangan dari perusahaan Stern dan Co pada tahun 1993 mengembangkan suatu konsep baru yaitu EVA (economic value added). EVA adalah suatu estimasi laba ekonomis yang sesungguhnya dari perusahaan dalam tahun berjalan, dan hal ini sangat berbeda dengan laba akuntansi. EVA yang mencoba mengukur nilai tambah yanng di hasilkan suatu perusahaan dengan dengan cara mengurangi beban biaya modal (cots of capital) yang timbul sebagai akibat intervensi yang dilakukan.

EVA yang positif menunjukkan bahwa perusahan berhasil menciptakan nilai bagi pemilik modal karena perusahaan mampu menghasilkan tingkat pengembalian yang melebihi tingakat modalnya. Hal ini sejalan dengan tujuan manajemen keuangan yaitu memaksimumkan nilai perusahaan. Sebaliknya EVA yang negatif menunjukkan nilai perusahaan menurun karena tingkat pengembalian lebih rendah dari biaya modal (Shiddiq, 2012).

Dan penilaian kinerja yang biasa digunakan lainnya yaitu Current Rasio. Current Rasio adalah rasio yang membandingkan antara aktiva lancar yang dimiliki perusahaan dengan hutang jangka pendek. Current rasio bertujuan untuk mengukur kemampuan perusahaan untuk melunasi kewajiban jangka pendeknya dengan aset lancar yang dimilikinya.

Konsep-konsep penialian kinerja dan pengaruhnya terhadap tingkat pengembalian investasi harus diperhatikan investor. Tujuannya adalah untuk kepastian investasi yang akan dilakukan

Berdasarkan data dan pernyataan-pernyataan yang telah diuraikan diatas, maka peneliti tertarik untuk melakukan penelitian lebih lanjut dengan judul: "Pengaruh Return On Investmen (ROI), Economic Value Adedd (EVA), dan Current Rasio (CR) Terhadap Return Saham Perusahaan Perkebunan yang Terdaftar di Bursa Efek Indonesia (BEI) Periode 2010-2014”.

Perumusan masalah adalah sebagai berikut:

1. Apakah Return On Invesment (ROI) berpengaruh terhadap return saham pada perusahaan perkebunan yang terdaftar di Bursa Efek Indonesia (BEI)?

2. Apakah Economic Value Added (EVA) berpengaruh terhadap return saham pada perusahaan perkebunan yang terdaftar di Bursa Efek Indonesia (BEI)?

3. Apakah Current Rasio (CR) berpengaruh terhadap return saham pada perusahaan perkebunan yang terdaftar di Bursa Efek Indonesia (BEI)?

4. Apakah Return On Invesment (ROI), Economic Value Added (EVA) dan Current Rasio (CR) secara simultan berpengaruh terhadap return saham pada perusahaan perkebunan yang terdaftar di Bursa Efek Indonesia (BEI)?

Sedangkan tujuan penelitian adalah sebagai berikut:

1. Untuk mengetahui pengaruh Return On Invesment (ROI) terhadap return saham pada perusahaan perkebunan yang terdaftar di Bursa Efek Indonesia (BEI). 
2. Untuk mengetahui pengaruh Economic Value Added (EVA) terhadap return saham pada perusahaan perkebunan yang terdaftar di Bursa Efek Indonesia (BEI).

3. Untuk mengetahui pengaruh Current Rasio (CR) terhadap return saham pada perusahaan perkebunan yang terdaftar di Bursa Efek Indonesia (BEI).

Untuk mengetahui pengaruh Return On Invesment (ROI), Economic Value Added (EVA), dan Current Rasio (CR) secara simultan terhadap return saham pada perusahaan perkebunan yang terdaftar di Bursa Efek Indonesia (BEI).

\section{TINJAUAN PUSTAKA \\ Return On Invesment (ROI)}

Return on investment (ROI) merupakan rasio yang digunakan untuk menghasilkan keuntungan (tingkat pengembalian) yang akan digunakan untuk menutupi investasi yang dikeluarkan (Sutrisno, 2008). Laba yang digunakan dalam untuk mengukur rasio ini adalah laba bersih setelah pajak atau earnings after tax (EAT).

Besarnya Return On Investment (ROI) dipengaruhi oleh dua faktor :

1. Turnover dari operating assets (tingkat perputaran aktiva yang digunakan untuk operasi).

2. Profit margin, yaitu besarnya keuntungan operasi yang dinyatakan dalam persentase dan jumlah penjualan bersih. Profit margin ini mengukur tingkat keuntungan yang dapat dicapai oleh perusahaan dihubungkan dengan penjualannnya.
Economic Value Added (EVA)

Munurut Lissa dalam harjono (2010) EVA adalah ukuran nilai tambah yang dihasilkan perusahaan sebagai akibat dari aktivitas atau strategi manajemen. Adanya EVA menjadi relevan untuk mengukur kinerja berdasarkan nilai ekonomis yang dihasilkan suatu perusahaan. Dengan adanya EVA, maka pemilik perusahan akan memberika imbalan aktvitas yang menambah nilai dan membuang fasilitas yang merusak atau mengurangi nilai keseluruhan suatu perusahaan dan membantu manajemen dalam menentukan tujuan internal perusahaan untuk implikasi jangka panjang dan bukan jangka pendek saja.

EVA memberikan tolak ukur yang baik tentang apakah perusahaan telah memberikan nilai tambah kepada pemegang saham. Oleh karna itu, jika manejer menfokuskan pada EVA, maka hal ini akan membantu memastikan bahwa mereka beroperasi dengan cara yang konsisten untuk memaksimumkan nilai perusahaan.

Menurut Stern dan Co Penilaian EVA dapat dinyatakan sebagai berikut:

1. Apabila EVA > 0, berarti nilai EVA positif yang menunjukkan telah terjadi proses nilai tambah pada perusahaan.

2. Apabila $\mathrm{EVA}=0$, menunjukkan posisi impas atau break even point

3. Apabila EVA $<0$, yang berarti eva negatif menunjukkan tidak terjadi proses nilai tambah.

\section{Current Rasio (CR)}

Current Rasio Adalah rasio yang membandingkan antara aktiva lancar yang dimiliki perusahaan dengan hutang jangka pendek. 
Aktiva lancar disini meliputi kas, piutang dagang, efek, persediaan dan aktiva lancar lainnya. Sedangkan hutang jangka pendek meliputi hutang dagang, hutang wesel, hutang bank, hutang gaji dan hutang lainnya yang segera harus dibayar (Sutrisno, 2008).

Current rasio bertujuan untuk mengukur kemampuan perusahaan untuk melunasi kewajiban jangka pendeknya dengan aset lancar yang dimilikinya. Nilai $\mathrm{CR}$ yang tinggi belum tentu baik ditinjau dari segi profitabilitasnya. (Sawir, 2005) menyatakan bahwa CR yang rendah akan berakibat pada menurunnya harga pasar saham perusahaan bersangkutan, namun $\mathrm{CR}$ yang terlalu tinggi belum tentu baik karena pada kondisi tertentu hal tersebut menunjukkan banyak dana perusahaan yang menganggur (aktivitas sedikit) yang pada akhirnya dapat mengurangi kemampuan laba perusahaan.

\section{Saham}

Saham merupakan surat berharga yang menunjukkan kepemilikan atau penyertaan modal investor di dalam suatu perusahaan. Artinya, jika seseorang membeli saham suatu perusahaan, berarti dia telah menyertakan modal ke dalam perusahaan tersebut sebanyak jumlah saham yang dibeli (Wiji dan Hendy, 2006).

Saham merupakan surat berharga yang dikeluarkan sebuah perusahaan dalam rangka menambah modal perusahaan tersebut. Jika sebuah perusahaan menjual sebagian sahamnya kepada masyarakat luas atau publik maka perusahaan tersebut dikatakan go public atau telah menjadi perusahaan publik, dalam arti kepemilikan atas perusahaan tersebut tidak hanya dimiliki sekelompok orang (atau orang-orang yang mendirikan perusahaan tersebut) namun kepemilikannya telah menyebar ke banyak pihak (Wiji dan Hendy, 2006).

Menurut Irham Fahmi dan Yovi lavianti (2011) dalam pasar modal ada dua jenis saham yang umum dikenal oleh publik yaitu saham biasa dan saham preferen.

1. Saham biasa

Saham biasa adalah suatu surat berharga yang dijual oleh suatu perusahaan yang menjelaskan nilai nominal (rupiah, dolar, yen dan lainnya) dimana pemegangnya diberi hak untuk mengikuti RUPS (rapat umum pemegang saham) dan RUPSLB (rapat umum pemegang saham luar biasa) serta berhak untuk menentukan membeli right issue (penjualan saham terbatas) atau tidak, yang selanjutnya diakhir tahun akan memperoleh keuntungan dalam bentuk deviden.

2. Saham Preferen

Saham preferen adalah suatu surat berharga yang dijual oleh suatu perusahaan yang menjelaskan nilai nominal (rupiah, dolar, yen dan lainnya) dimana pemegangnya akan memperoleh pendapatan tetap dalam bentuk deviden yang akan diterima setiap kuartal (tiga bulan).

\section{Return Saham}

Return saham merupakan tingkat keuntungan yang diperoleh investor atas investasi yang dilakukannya. Investasi dapat diartikan sebagai sebuah kegiatan 
penempatan dana pada satu atau lebih aset selama periode tertentu dengan harapan dapat memperoleh penghasilan atau peningkatan investasi (Jones 1996, dalam Subalno, 2009). Oleh karena itu, tujuan investasi adalah untuk meningkatkan kesejahteraan investor, baik sekarang ataupun di masa yang akan datang.

Return saham berbanding positif dengan resiko, artinya semakin besar resiko yang ditanggung oleh pemegang saham, maka return (keuntungan) akan semakin besar pula, begitu sebaliknya.

Menurut Abdul Halim (2005)

Return Saham terdiri dari dua komponen utama, yaitu:

1. Capital Gain yaitu merupakan keuntungan bagi investor yang diperoleh dari kelebihan harga jual di atas harga beli yang keduanya terjadi di pasar sekunder.

2. Yield merupakan pendapatan atau aliran kas yang diterima secara periodik. Misalnya berupa deviden atau bunga.

\section{Penelitian Terdahulu}

Penelitian yang dilakukan oleh Rahman (2008) meneliti mengenai perbandingan kinerja dengan keuangan perusahaan dengan metoda EVA, ROA dan pengaruhnya terhadap Return saham pada perusahaan yang tergabung dalam Indeks LQ 45 di Bursa Efek Indonesia. Hasilnya menunjukkan bahwa metoda ROA memiliki pengaruh yang positif dan siginfikan terhadap return saham. Sedangkan metoda EVA tidak memiliki pengaruh. Dan menyimpulkan bahwa pengukuran kinerja keuangan dengan metoda ROA lebih baik dibandingkan dengan metoda EVA dalam pengaruhnya terhadap return saham.

Lilis dan Deddy (2008) melakukan penelitian tentang pengaruh Return On Investment dan Ecconomic Value Added pada Return saham pada perusahaan manufaktur di Bursa Efek Jakarta (BEJ) periode 2003-2006. Hasil penelitian menunjukkan bahwa Return On Investment dan Ecconomic Value Added baik secara parsial maupun bersama-sama berpengaruh positif dan signifikan terhadap Return saham.

Subalno (2009) melakukan penelitian tentang analisis pengaruh faktor fundamental dan kondisi ekonomi terhadap return saham pada perusahaan otomotif di BEI periode 2003-2007, hasil penelitian menunjukkan bahwa ROA, Nilai tukar, dan Suku bunga SBI berpengaruh terhadap return saham, sedangkan CR, DER, dan TATO tidak berpengaruh terhadap return saham.

Harjono (2010) melakukan penelitian tentang pengaruh penilaian kinerja dengan ROI dan EVA terhadap return saham saham pada pererusahaan yang tergabung dalam indeks LQ 45 di Bursa Efek Indonesia periode 2007-2008. Hasilnya menunjukkan bahwa ROI dan EVA tidak mempunyai pengaruh signifikan terhadap return saham.

Hermi dan Ary Kurniawan (2011) melakukan penelitian tentang pengaruh kinerja keuangan terhadap return saham pada perusahaan manufaktur yang terdaftar di Bursa Efek Indonesia periode 2008-2010. Hasilnya menunjukkan bahwa hanya 
EPS yang berpengaruh signifikan terhadap return saham. Sedangkan ROI, ROE, NPM, EPS, dan PBV tidak berpengaruh terhadap return saham.

Kusumo (2011) melakukan penelitian tentang analisis pengaruh rasio keuangan terhadap return saham pada perusahan non bank LQ45, hasil penelitian menunjukkan bahwa TATO berpengaruh terhadap return saham. Sedangkan CR, DER, ROA, tidak berpengaruh terhadap return saham.

\section{METODE PENELITIAN \\ Populasi dan Sampel Penelitian}

Populasi dalam penelitian ini adalah perusahaan perkebunan yang terdaftar di Bursa Efek Indonesia (BEI) selama periode penelitian yaitu tahun 2010-2014.Jumlah populasi yang ditemukan oleh peneliti sebanyak 16 perusahaan.

Sampel dalam penelitian ini adalah 8 perusahaan perkebunan yang terdaftar di Bursa Efek Indonesia (BEI) Tahun 2010-2014. Pemilihan sampel penelitian ini secara purposive sampling. Kriteria perusahaan yang menjadi sampel dalam penelitian ini adalah:

1. Perusahan-perusahaan

perkebunan yang telah go public atau telah terdaftar di Bursa Efek Indonesia (BEI).

2. Perusahaan-perusahaan perkebunan yang memiliki tanggal IPO sebelum tahun 2010 sampai dengan 2014.

3. Perusahaan-perusahaan perkebunan yang mengeluarkan laporan keuangan secara lengkap dari tahun 2010 sampai dengan tahun 2014 yang terdaftar di Bursa Efek Indonesia (BEI).

\section{Metode Pengumpulan Data}

Metode pengumpulan data yang digunakan dalam penelitian ini adalah metode dokumentasi, yaitu metode pengumpulan data dengan mempelajari catatan dan dokumendokumen perusahaan baik dalam bentuk dokumen maupun petunjukpetunjuk guna mendapatkan data yang diperlukan. Data yang di kumpulkan merupakan data sekunder, berupa laporan keuangan yang di peroleh dari webside Indonesian Stock Exchange (IDX), Indonesian Capital Market Directory (ICMD) dan literatur terkait lainnya.

\section{Variabel Penelitian}

\section{Variabel Terikat}

Variabel Terikat adalah variabel yang dipengaruhi oleh variabel bebas. Dalam penelitian ini variabel terikat yang digunakan adalah return saham.

Return saham adalah tingkat keuntungan yang diperoleh pemodal atau investor atas investasi yang dilakukannya. Konsep dari penelitian ini menggunakan konsep capital gain yaitu selisih antara harga saham periode saat ini (Closing pricebulanan pada periode $\mathrm{t}$ ) dengan harga saham pada periode sebelumnya (Closing price bulanan pada periode $\mathrm{t}-1$ ) dibagi dengan harga saham pada periode sebelumnya (Closing price bulanan pada periode t-1). Menurut Fahmi (2013) Return saham dapat dihitung dengan rumus:

$$
\begin{aligned}
& \mathrm{Ri}=\frac{\mathrm{Pt}-\mathrm{Pt}-1}{\mathrm{Pt}-1} \\
& \mathrm{dimana:} \\
& \mathrm{Ri}=\text { Return saham } \\
& \mathrm{Pt}=\begin{array}{c}
\text { Harga saham pada } \\
\text { periode } \mathrm{t}
\end{array}
\end{aligned}
$$


Pt-1 = $\begin{gathered}\text { Harga saham pada } \\ \text { periode } \mathrm{t}-1\end{gathered}$ Variabel bebas

Yang dimaksud variabel bebas adalah variabel yang mempengaruhi besar kecilnya variabel terikat. Penelitian ini memakai tiga variabel bebas $(\mathrm{X} 1, \mathrm{X} 2, \mathrm{X} 3)$ yaitu:

\section{Return On Investment (ROI)}

Return On Investment (ROI) merupakan rasio yang digunakan untuk mengukur kemampuan perusahaan dalam menghasilkan keuntungan (tingkat pengembalian), yang digunakan untuk menutupi investasi yang dikeluarkan (Sutrisno, 2008).

Rumus:

$$
\mathrm{ROI}=\frac{\mathrm{EAT}}{\text { Investasi }}
$$

\section{Economic Value Added (EVA)}

EVA merupakan indikator tentang adanya perubahan nilai dari suatu investasi. EVA mengukur nilai tambah yang dihasilkan suatu perusahan dengan cara mengurangi biaya modal yang timbul sebagai akibat investasi yang dilakukan.

Langkah-langkah untuk menghitung EVA (Rokhayati dalam Shidiq, 2012)

Menghitung Economic Value Adedd (EVA):

Rumus:

EVA = NOPAT - Capital Charges

Atau

EVA $=$ NOPAT $-($ WACC $\mathrm{x}$

Invested Capital)

3. Current Rasio (CR)

Current Rasio Adalah rasio yang membandingkan antara aktiva lancar yang dimiliki perusahaan dengan hutang jangka pendek. Aktiva lancar disini meliputi kas, piutang dagang, efek, persediaan dan aktiva lancar lainnya. Sedangkan hutang jangka pendek meliputi hutang dagang, hutang wesel, hutang bank, hutang gaji dan hutang lainnya yang segera harus dibayar (Sutrisno, 2008).

Rumus:

Current Rasio $=\frac{\text { Aktiva Lancar }}{\text { Hutang Lancar }}$

\section{Metode Analisis Data}

Dalam penelitian ini digunakan analisis regresi data panel. Data panel adalah jenis data yang merupakan gabungan dari data time series (runtut waktu) dan cross section (seksi silang) (Winarno, 2011). Keunggulan dari penggunaan data panel salah satunya adalah dapat memberikan data yang lebih informatif dan lebih baik dalam mendeteksi dan mengatur efek yang tidak dapat diamati dalam data time series dan cross section.

Penelitian ini dibuat dengan menggunakan multiple regression yang didalam pengujiannya akan dilakukan dengan bantuan program EViews versi6.0.Menurut Sofyan (2011) dan Nachrowi (2006) Tahapan yang digunakan dalam menggunakan Regresi data panel adalah:

1. Melakukan pemilihan model terbaik regresi data panel antara pendekatan Common Effect, Fixed Effect, Random Effect.

2. Melakukan Pemilihan model terbaik regresi data panel menggunakan $\cdot \mathrm{Uji}$ Chow dan Uji Housman.

3. Melakukan uji kualitas data dengan menggunakan Asumsi klasik yaitu Multikolinieritas dan Heteroskedastisitas.

1. Melakukan Uji Statistik dan Uji Hipotesis : Uji Parsial (Uji t), Uji 
Simultan/Fisher (Uji F) dan Uji Koefisien Determinasi (R2).

\section{PEMBAHASAN}

Teknik estimasi data panel yang digunakan dalam peneltian ini adalah dengan menggunakan model Fixed Effect dan Random Effect. Untuk menentukan model yang tepat maka dilakukan uji Housman dengan probabilitas 5\%. Hipotesis yang digunakan adalah :

H0 : Metode random effect

$\mathrm{H} 1$ : Metode fixed effect
Jika nilai $p$-value cross section random $<\alpha=5 \%$ maka $\mathrm{H} 0$ ditolak atau metode yang digunakan adalah metode Fixed Effect. Sebaliknya, jika nilai $p$-value cross section random $\geq$ $\alpha=5 \%$ maka $\mathrm{H} 0$ diterima atau metode yang digunakan adalah metode Random Effect.

Sebelum melakukan uji Housman, terlebih dahulu dilakukan pemilihan model Fixed Effect dan Random Effect. Hasil dari pengujian model Fixed Effect dan Random Effect adalalah sebagai berikut :

Tabel 1.

Pemilihan Model Fixed Effect

\begin{tabular}{crlrr}
\hline \hline \multicolumn{1}{c}{ Variable } & Coefficient & Std. Error & t-Statistic & Prob. \\
\hline \hline C & -5.407306 & 1.757150 & -3.077316 & 0.0045 \\
ROI & 1.343095 & 0.637707 & 2.106131 & 0.0440 \\
EVA & 7.349856 & 2.375690 & 3.093778 & 0.0043 \\
CR & -0.157439 & 0.135301 & -1.163617 & 0.2541 \\
\hline \hline \multicolumn{5}{c}{ Effects Specification } \\
\hline \hline Cross-section fixed (dummy variables) & \\
\hline \hline R-squared & 0.673907 & Mean dependent var & 0.604139 \\
Adjusted R-squared & 0.561461 & S.D. dependent var & 0.056984 \\
S.E. of regression & 0.037736 & Akaike info criterion & -3.487989 \\
Sum squared resid & 0.041296 & Schwarz criterion & -3.023547 \\
Log likelihood & 80.75978 & Hannan-Quinn criter. & -3.320062 \\
F-statistic & 5.993158 & Durbin-Watson stat & 1.789288 \\
Prob(F-statistic) & 0.000071 & & \\
\hline \hline
\end{tabular}

Sumber: Data Olahan Eviews 6

Berdasarkan hasil perhitungan model Fixed Effect diatas, dapat dilihat nilai Adjust R-squaresebesar 0.561461 dan probabilitas $\mathrm{F}$ yakni sebesar 0,000071, Sehingga dapat disimpulkan bahwa model ini baik digunakan. Namun untuk perbandingan dalam menentukan model mana yang paling tepat digunakan, dilakukan pengujian Random Effect. Hasil pengujian model Random Effect adalah sebagai berikut: 
Tabel 2.

Pemilihan Model Random Effect

\begin{tabular}{|c|c|c|c|c|}
\hline Variable & Coefficient & Std. Error & t-Statistic & Prob. \\
\hline $\mathrm{C}$ & -4.720651 & 1.443842 & -3.269507 & 0.0024 \\
\hline ROI & 0.658832 & 0.562515 & 1.171226 & 0.2492 \\
\hline EVA & 6.906316 & 2.046786 & 3.374224 & 0.0018 \\
\hline $\mathrm{CR}$ & 0.019837 & 0.079752 & 0.248733 & 0.8050 \\
\hline \multicolumn{5}{|c|}{ Effects Specification } \\
\hline & & & S.D. & Rho \\
\hline Cross-section random & & & 0.021333 & 0.2422 \\
\hline Idiosyncratic random & & & 0.037736 & 0.7578 \\
\hline \multicolumn{5}{|c|}{ Weighted Statistics } \\
\hline R-squared & 0.265655 & \multirow{5}{*}{\multicolumn{2}{|c|}{$\begin{array}{l}\text { Mean dependent var } \\
\text { S.D. dependent var } \\
\text { Sum squared resid } \\
\text { Durbin-Watson stat }\end{array}$}} & 0.374824 \\
\hline Adjusted R-squared & 0.204460 & & & 0.047273 \\
\hline S.E. of regression & 0.042165 & & & 0.064003 \\
\hline F-statistic & 4.341094 & & & 1.343880 \\
\hline \multirow[t]{2}{*}{ Prob(F-statistic) } & 0.010378 & & & \\
\hline & \multicolumn{3}{|c|}{ Unweighted Statistics } & \\
\hline R-squared & 0.256314 & \multirow{2}{*}{\multicolumn{2}{|c|}{ Mean dependent var }} & 0.604139 \\
\hline Sum squared resid & 0.094180 & & Durbin-Watson stat & 0.913275 \\
\hline
\end{tabular}

Sumber: Data Olahan Eviews 6

Berdasarkan pengujian dengan model Random Effect diatas, diperoleh hasil Adjust R-square sebesar0.204460 dan nilai probabilitas F yaitu sebesar0.010378. Nilai $F$ ini lebih besar dibandingkan dengan hasil pengujian model Fixed Effect, namun sama-sama kurang

Tabel 3.

\section{Hasil Uji Housman}

\begin{tabular}{lrrr}
\hline \hline Test Summary & Chi-Sq. Statistic & Chi-Sq. d.f. & Prob. \\
\hline \hline Cross-section random & 11.945562 & 3 & 0.0076 \\
\hline \hline
\end{tabular}

Sumber: Data Olahan Eviews 6 dari nilai signifikan yaitu 5\%. Untuk menentukan model yang paling tepat, selanjutnya akan dilakukan uji Housman. Hasil Uji Housman adalah sebagai berikut : 
Dapat dilihat dari tabel di atas berdasarkan uji Housman pengunaan model fixed effect atau efek tetap tidak memiliki dampak dapat ditolak, dengan nilai $F$ hitung sebesar 11.945562 dan $p$ value sebesar 0.0076 lebih kecil dari taraf signifikansi $5 \%$ maka sesuai dengan ketentuan pengambilan keputusan bahwa H0 diterima. Dengan demikian dapat dikatakan bahwa model efek tetap atau fixed effect memberikan nilai yang signifikan sehingga menjadi alternatif yang dipilih.

\section{Uji Kualitas Data dengan Asumsi} Klasik

\section{Uji Multikolinieritas}

Dalam penelitian ini penulis akan melihat multikolinearitas dengan menguji koefisien korelasi (r) berpasangan yang tinggi di antara variabel-variabel penjelas. Menurut Nachrowi (2006) jika koefisien korelasi diatas 0.8 maka diduga terjadinya multikolinearitas dalam model. Sebaliknya jika koefisien korelasi rendah maka diduga model tidak mengandung multikolinearitas.

\begin{tabular}{|c|c|c|c|}
\hline & ROI & EVA & CR \\
\hline ROI & 1 & 0.347369 & 0.599247 \\
\hline EVA & 0.347369 & 1 & 0.344300 \\
\hline CR & 0.599247 & 0.344300 & 1 \\
\hline
\end{tabular}

Berdasarkan tabel hasil analisis uji multikolinearitas dengan correlation matrix di atas terlihat bahwa korelasi antar variabel independen antara ROI dan EVA maupun sebaliknya sebesar0.347369, antara ROI dan CR maupun sebaliknya sebesar0.599247, antara EVA dan CR maupun sebaliknya sebesar 0.344300 .

Terlihat dari tabel diatas nilai korelasi variabel independen (ROI, EVA, CR) tertinggi hanya mencapai0.599247 yaitu antara ROI dan CR maupun sebaliknya. Karena nilai $\quad 0.599247<0.8 \quad$ sehingga diputuskan tidak terdapat multikolinearitas. Hasil ini menginformasikan model Ordinary Least Square (OLS) yang dilakukan dapat dikatakan terbebas dari gejala multikolinearitas.

\section{Uji Heteroskedastisitas}

Untuk melacak keberadaan heteroskedastisitas dalam penelitian ini digunakan uji White. Uji Dimana pengujiannya adalah jika nilai probability $O b s^{*}$ Rsquared lebih besar dari taraf nyata 5\%. Maka hipotesis alternatif adanya heteroskedastisitas dalam model ditolak. Hasil uji heteroskedastisitas dapat dilihat pada tabel di bawah ini:

Sumber: Data Olahan Eviews 6

Tabel 4.

Hasil Uji Heteroskedastisitas

Heteroskedasticity Test: White

\begin{tabular}{llll}
\hline \hline F-statistic & 0.742557 & Prob. F(3,36) & 0.5337 \\
Obs*R-squared & 2.330950 & Prob. Chi-Square(3) & 0.5066 \\
Scaled explained SS & 1.423804 & Prob. Chi-Square(3) & 0.7000 \\
\hline \hline
\end{tabular}

Test Equation:

Dependent Variable: RESID ${ }^{\wedge} 2$

Method: Least Squares

Date: 04/28/16 Time: 15:31 
Sample: 140

Included observations: 40

\begin{tabular}{lrllr}
\hline \hline \multicolumn{1}{c}{ Variable } & Coefficient & Std. Error & t-Statistic & Prob. \\
\hline \hline C & -0.029500 & 0.045554 & -0.647576 & 0.5214 \\
ROI^2 $_{\text {EVA^2 }}$ & 0.018863 & 0.026884 & 0.701655 & 0.4874 \\
CR^2 & 0.049791 & 0.094636 & 0.526134 & 0.6020 \\
\hline \hline R-squared & -0.005922 & 0.004040 & -1.465577 & 0.1514 \\
Adjusted R-squared & 0.058274 & Mean dependent var & 0.002234 \\
S.E. of regression & -0.020203 & S.D. dependent var & 0.002779 \\
Sum squared resid & 0.002806 & Akaike info criterion & -8.819133 \\
Log likelihood & 0.000284 & Schwarz criterion & -8.650245 \\
F-statistic & 180.3827 & Hannan-Quinn criter. & -8.758068 \\
Prob(F-statistic) & 0.742557 & Durbin-Watson stat & 1.724916 \\
\hline \hline
\end{tabular}

Sumber: Data Olahan Eviews 6

Berdasarkan uji White yang telah dilakukan pada tabel diatas dapat disimpulkan tidak terjadi gejala heteroskedastisitas. Hal ini ditunjukkan dan besarnya Obs*RSquared 2.330950 dan prob. ChiSquare $0.5066>0.05$.

\section{Uji Hipotesis}

\section{Uji Parsial (Uji t)}

Uji t bertujuan untuk menguji pengaruh masing-masing variabel independen yaitu Return On Investment (ROI), Economic Value Added (EVA), Current Rasio (CR) terhadap variabel depanden yaitu Return Saham.Pengujian terhadap hasil regresi dilakukan dengan menggunakan uji $\mathrm{t}$ pada derajat keyakinan $\alpha=5 \%$. Kriteria pengujiannya adalah:

1. Jika tingkat signifikansi lebih besar dari $5 \%$ maka dapat disimpulkan bahwa H0 diterima, sebaliknya Ha ditolak.

2. Jika tingkat signifikansi kurang dari 5\% maka dapat disimpulkan bahwa $\mathrm{H} 0$ tolak, sebaliknya $\mathrm{Ha}$ diterima.

Dari hasil pengujian statistik analisis regresi data panel menggunakan software Eviews versi 6, diperoleh hasil sebagai berikut:

Tabel 5.

Hasil Regresi Uji t

\begin{tabular}{crrrr}
\hline \hline Variable & Coefficient & Std. Error & t-Statistic & Prob. \\
\hline \hline C & -5.407306 & 1.757150 & -3.077316 & 0.0045 \\
ROI & 1.343095 & 0.637707 & 2.106131 & 0.0440 \\
EVA & 7.349856 & 2.375690 & 3.093778 & 0.0043 \\
CR & -0.157439 & 0.135301 & -1.163617 & 0.2541 \\
\hline \hline
\end{tabular}


Sumber: Data Olahan Eviews 6

Berdasarkan hasil analisis regresi data panel hasil pengujian hipotesis dapat dimaknai sebagai berikut:

1. Pengaruh ROI terhadap return saham

Berdasarkan tabel diatas diperoleh hasil estimasi variabel Return On Investment (ROI) nilait $_{\text {hitung }}(2,106)>t_{\text {tabel }}(2,028)$ dan nilai sig. $(0,044)<0,05$. Maka dapat disimpulkan Ho ditolak dan Ha diterima, bahwa variabel ROI berpengaruh positif terhadap Return Saham pada perusahaan perkebunan yang terdaftar di Bursa Efek Indonesia 2010-2014.

2. Pengaruh EVA terhadap return saham

Berdasarkan tabel diatas diperoleh hasil estiimasi variabel EVA nilait hitung $(3,0937)>t_{\text {tabel }}$ $(2,028)$ dan nilai sig. $(0,0043)<$ 0,05. Maka dapat disimpulkan Ho ditolak dan $\mathrm{Ha}$ diterima, bahwa variabel EVA berpengaruh positif terhadap Return Saham pada perusahaan perkebunan yang terdaftar di Bursa Efek Indonesia 2010-2014.

3. Pengaruh CR terhadap return saham

Berdasarkan tabel diatas diperoleh hasil estimasi variabel CR nilait ${ }_{\text {hitung }}(-1,1636)>t_{\text {tabel }}$ $(-2,028)$ dan nilai sig. $(0,2541)>$ 0,05. Maka dapat disimpulkan Ho diterima dan Ha ditolak, bahwa variabel $\mathrm{CR}$ tidak berpengaruh terhadap Return Saham pada perusahaan perkebunan yang terdaftar di Bursa Efek Indonesia 2010-2014.

\section{Uji Simultan (Uji F)}

Pengujian ini dilakukan dengan membandingkan nilai $\mathrm{F}_{\text {hitung }}$ dengan $\mathrm{F}_{\text {tabel }}$. Apabila $\mathrm{F}_{\text {hitung }}>\mathrm{F}_{\text {tabel }}$ dengan signifikasi dibawah $5 \%$ $(0,05)$ maka secara bersama-sama (simultan) variabel bebas berpengaruh signifikan terhadap variabel terikat, begitu sebaliknya. Hasil uji $F$ dapat dilihat pada tabel dibawah ini:

Tabel 6.

Hasil Uji Simultan (Uji F)

\begin{tabular}{lllr}
\hline \hline R-squared & 0.673907 & Mean dependent var & 0.604139 \\
Adjusted R-squared & 0.561461 & S.D. dependent var & 0.056984 \\
S.E. of regression & 0.037736 & Akaike info criterion & -3.487989 \\
Sum squared resid & 0.041296 & Schwarz criterion & -3.023547 \\
Log likelihood & 80.75978 & Hannan-Quinn criter. & -3.320062 \\
F-statistic & 5.993158 & Durbin-Watson stat & 1.789288 \\
Prob(F-statistic) & 0.000071 & & \\
\hline
\end{tabular}

Sumber: Data Olahan Eviews 6

dengan demikian diketahui
$\mathrm{F}_{\text {hitung }}(5,993)>\mathrm{F}_{\text {tabel }}(2,866)$
dengan nilai sig. $(0,000071)<0,05$.
Artinya adalah bahwa variabel independen secara bersama-sama berpengaruh positif signifikan terhadap variabel dependen.

Uji Koefisien Determinasi $\left(R^{2}\right)$ 
Tabel 7.

Hasil Uji Koefisien Determinasi $\left(\mathbf{R}^{\mathbf{2}}\right)$

\begin{tabular}{lllr}
\hline \hline R-squared & 0.673907 & Mean dependent var & 0.604139 \\
Adjusted R-squared & 0.561461 & S.D. dependent var & 0.056984 \\
S.E. of regression & 0.037736 & Akaike info criterion & -3.487989 \\
Sum squared resid & 0.041296 & Schwarz criterion & -3.023547 \\
Log likelihood & 80.75978 & Hannan-Quinn criter. & -3.320062 \\
F-statistic & 5.993158 & Durbin-Watson stat & 1.789288 \\
Prob(F-statistic) & 0.000071 & & \\
\hline
\end{tabular}

Sumber: Data Olahan Eviews 6

Dari tabel di atas terlihat nilaiAdjustedR Square nya adalah sebesar 0,561461. Hal ini berarti bahwa persentase sumbangan pengaruh variabel independen yang digunakan dalam penelitian, yaitu ROI, EVA, CR terhadap Return Saham perusahaan perkebunan adalah sebesar $56,15 \%$. Dengan kata lain variabel independen dapat menjelaskan variabel dependennya sebesar $56,15 \%$, sedangkan sisanya $43,85 \%$ dijelaskan oleh variabel lain yang tidak dimasukkan dalam penelitian ini.

\section{PEMBAHASAN}

1. Pengaruh Return On Investment (ROI) terhadap Return Saham

Berdasarkan pengujian hipotesis ROI yang telah dilakukan hasil penelitian ini menunjukkan nilai $t_{\text {hitungyang diperoleh sebesar }}$ $(2,106)>t_{\text {tabel }}(2,028)$ dan tingkat signifikansi $0,0440<0,05$. Maka dapat disimpulkan bahwa $\mathrm{Ha}$ diterima dan Ho ditolak. Artinya bahwa variabel independen ROI berpengaruh positif dan signifikan terhadap return saham pada perusahaan perkebunan yang terdaftar di BEI tahun 2010-2014.

Semakin besar ROI maka kinerja perusahaan tersebut semakin baik, hal ini juga menunjukkan semakin efektifnya perusahaan dalam memamfaatkan asetnya untuk menghasilkan laba setelah pajak. Dengan semakin meningkatmya ROI maka kinerja perusahaan yang ditinjau dari profitabilitas semakin baik. Tingkat profitabilitas perusahaan yang baik tentu akan menarik minat investor untuk memiliki saham perusahaan tersebut, karena ROI yang tinggi akan meningkatkan tingkat pengembalian (return) yang dinikmati investor. Dengan demikian dapat dikatakan bahwa semakin tinggi ROI menunjukkan semakin efektif perusahaan memamfaatkan asetnya untuk menghasilkan laba bersih setelah pajak. Jika minat investor untuk membeli saham perusahaan meningkat, maka harga saham perusahaan juga meningkat yang diikuti oleh tingkat pengembalian (return) saham besar.

Hasil ini sejalan dengan penelitian Lilis dan Deddi (2008) yang menyimpulkan bahwa Return On Investment berpengaruh signifikan terhadap return saham.

2. PengaruhEconomic ValueAdded (EVA) terhadap Return Saham

Berdasarkan pengujian hipotesis EVA yang telah dilakukan 
hasil penelitian menunjukkan nilai $t_{\text {hitungyang diperoleh }}(3,0937)$ $>t_{\text {tabel }} \quad(2,028)$ dan tingkat signifikansi sebesar $0,0043<0,05$. Maka dapat disimpulkan bahwa $\mathrm{Ha}$ diterima dan Ho ditolak. Artinya Variabel EVA berpengaruh positif dan signifikan terhadap return saham.

Perubahan yang terjadi pada EVA akan mempengaruhi naik turunnya return saham dan hasil analisis data menunjukkan perubahan yang searah antara variabel bebas Economic Value Added (EVA) dengan variabel terikat Return Saham yang artinya apabila variabel EVA naik maka variabel Return Saham juga akan naik. Hasil uji parsial yang menunjukkan hasil signifikan mengindikasikan bahwa investor menilai suatu perusahaan dengan melihat dari sudut pandang nilai tambah atas investasinya. Apabila EVA tinggi maka ketertarikan investor terhadap saham juga tinggi sehinga akan mempengaruhi harga saham dan pengembalian saham bagi pemilik juga akan meningkat.

Penelitian ini mendukung penelitian dari Lilis dan Deddi (2008) yang menguji pengaruh ROI dan EVA terhadap return saham perusahaan manufaktur yang terdaftar di Bursa Efek Jakarta periode 2004-2006. Hasil penelitian menunjukkan bahwa EVA berpengaruh secara signifikan terhadap return saham.

3. Pengaruh Current Rasio (CR) terhadap Return Saham

Berdasarkan pengujian hipotesis CR yang telah dilakukan hasil penelitian ini menunjukkan nilai $t_{\text {hitung }}$ yang diperoleh sebesar (-
1,1636) $>t_{\text {tabel }}(-2,028)$ dan tingkat signifikansi sebesar 0,2541>0,05. Maka dapat disimpulkan bahwa $\mathrm{Ha}$ ditolak dan Ho diterima. Artinya bahwa variabel independen CR tidak berpengaruh secara signifikan terhadap Return Saham pada perusahaan perkebunan yang terdaftar di BEI tahun 2010-2014.

Current ratio mencerminkan kemampuan perusahaan dalam memenuhihutang jangka pendeknya dengan menggunakan aktiva lancar yang dimilikinya. Menurut Sawir (2005) Current Rasio(CR) yang terlalu tinggi belum tentu baik karena pada kondisi tertentu hal tersebut menunjukkan banyak dana perusahaan yang menganggur (aktivitas sedikit) yang pada akhirnya dapat mengurangi kemampuan laba perusahaan. Current ratio yang tinggi tidak mempengaruhi minat investor dalam menanamkan modalnya, karena tingginya nilai $\mathrm{CR}$ menunjukkan kemampuan perusahaan dalam mengelola aktiva lancar yang kurang baik, sehingga mengakibatkan banyak aktiva lancar yang menganggur dan tidak di optimalkan oleh perusahaan yang berakibat pada menurunnya minat investor dalam menanamkan modalnya. Minat investor yang menurun ini berimbas pada turunnya harga saham perusahaan sehingga mengakibatkan return saham juga ikut menurun.

Hasil ini sejalan dengan Subalno (2009) yang menyimpulkan bahwa Current Rasio (CR) tidak mempunyai pengaruh terhadap Return saham. 


\section{PENUTUP}

\section{Kesimpulan}

Kesimpulan dari uji secara parsial adalah Return On Investment (ROI) berpengaruh positif dan signifikan terhadap Return Saham perusahaan perkebunan yang terdaftar di Bursa Efek Indonesia tahun 2010-2014 dengan nilai $t_{\text {hitung }}$ $(2,1061)>t_{\text {tabel }}(2,028)$ dan nilai sig. $(0,0440)<0,05$. Economic Value Added (EVA) berpengaruh positif dan signifikan terhadap Return Saham perusahaan perkebunan yang terdaftar di Bursa Efek Indonesia tahun 2010-2014 dengan nilait hitung $(3,0937)>t_{\text {tabel }}(2,028)$ dan nilai sig. $(0,0043)<0,05$. Dan Current Rasio (CR) tidak berpengaruh secara signifikan terhadap Return Saham perusahaan perkebunan yang terdaftar di Bursa Efek Indonesia tahun 2010-2014 dengan nilai $t_{\text {hitung }}(-1,1636)>t_{\text {tabel }}(-2,028)$ dan nilai sig. $(0,2541)>0,05$.

Hasil uji simultan adalah Return On Investment (ROI), Economic Value Added (EVA), Current Rasio (CR) secara simultan berpengaruh positif dan signifikan terhadap Return Saham perusahaan perkebunan yang terdaftar di Bursa Efek Indonesia tahun 2010-2014 dengan nilai $\mathrm{F}_{\text {hitung }}(5,9931)>\mathrm{F}_{\text {tabel }}$ $(2,866)$ dengan nilai sig. $(0,00071)<$ 0,05 .

\section{Saran}

Berdasarkan kesimpulan di atas, maka saran yang diberikan peneliti berkaitan dengan hasil penelitian ini yaitu :

1. Bagi para investor dalam pengembalian investasi di Bursa Efek Indonesia (BEI) hendaknya tidak hanya memperhatikan faktor-faktor penilaian kinerja saja, tetapi juga memperhatikan faktor-faktor eksternal seperti perubahan tingkat inflasi, suku bunga dan rasio-rasio lainnya.

2. Bagi perusahaan diharapkan lebih memperhatikan kemampuan perusahaan dalam menghasilkan dan mengoptimalkan laba perusahaan yang dapat mempengaruhi return saham.

3. bagi peneliti selanjutnya diharapkan dapat mencoba melakukan penelitian dengan populasi penelitian tidak hanya terbatas pada satu jenis perusahaan, dan juga menambah faktor-faktor eksternal perusahaan sebagai variabel penelitian seperti perubahan tingkat inflasi, suku bunga dan rasio-rasio lainnya.

\section{DAFTAR PUSTAKA}

Abdul Halim. 2005. Analisis Investasi. Edisi Dua Salemba Empat: Jakarta.

Agnes, Sawir. 2005. Analisis Kinerja Keuangan dan Perencanaan Keuangan Perusahaan. PT. Gramedia Pustaka Utama: Jakarta.

Ajija, Shochrul Rohmatul, dkk. 2011. Cara Cerdas Menguasai Eviews, Salemba Empat. Jakarta.

Alwi Z Iskandar. 2008. Pasar Modal Teori dan Aplikasi, Penerbit Yayasan Pancur Siwah. Jakarta.

Fahmi, Irham dan Hadi, Yovi Lavianti. 2011. Teori Portofolio dan Analisis investasi. Alfabeta: Bandung.

Fahmi, Irham. 2013. Rahasia Saham dan Obligasi. Alfabeta: Bandung. 
Gujarati, Damodar. 2006. Dasardasar Ekonometrika, edisi ketiga Erlangga: Jakarta.

Hermi dan Kurniawan, Ary. 2011. Pengaruh Kinerja Keuangan Terhadap Return Saham pada Perusahaan Manufaktur. Jurnal Informasi, Perpajakan, Akuntansi dan Keuangan Publik, volume 6 , no. 2:83-95.

Kasmir. 2012. Bank dan Lembaga Keuangan Lainnya. Edisi Revisi. PT. Raja Grafindo Persada: Jakarta.

Lilis Puspitawati dan Deddy Supardi. 2008. Pengaruh Return On Investment dan Ecconomic Value Added pada Return Saham Perusahaan Manufaktur. Jurnal Trikonomika, volume 7, no. 2:106-113.

Nachrowi, D. dan Hardius Usman. 2006. Pendekatan Populer dan Praktis EKONOMETRIK Untuk Analisis Ekonomi dan Keuangan. FEUI: Jakarta.

Purwanta, Wiji dan Fakhruddin, Hendy. 2006. Mengenal Pasar Modal. Salemba Empat. Jakarta.

Shiddiq, Nieki. 2008. Pengaruh Economic Value Added, Rasio Profitability dan Earning Per Share terhadap Harga Saham Perusahaan Manufaktur di BEI. Skripsi Universitas Diponegoro: Semarang.

Sofyan Yamin, Lien A. Rachmach, Heri Kurniawan, 2011 Regresi dan Korelasi dalam genggaman anda Aplikasi dengan software SPSS, Eviews, MINITAB, dan STATGRAPHICS. Salemba Empat: Jakarta.

Sugiyono. 2010. Metode Penelitian Bisnis. Alfabeta: Bandung.
Suliyanto. 2011. Ekonomitrika Terapan: Teori dan Aplikasi dengan SPSS. ANDI: Jogyakarta.

Sunardi, Harjono. 2010. PengaruhPenilaian Kinerja dengan ROI dan EVA Terhadap Return Saham pada Perusahaan yang Tergabung dalam Indeks LQ 45 di Bursa Efek Indonesia. Jurnal Akuntansi, vol.2, No.1:70-92.

Sutrisno, 2008. Manajemen Keuangan Teori, Konsep dan Aplikasi. Ekonisia: Yogjakara. 